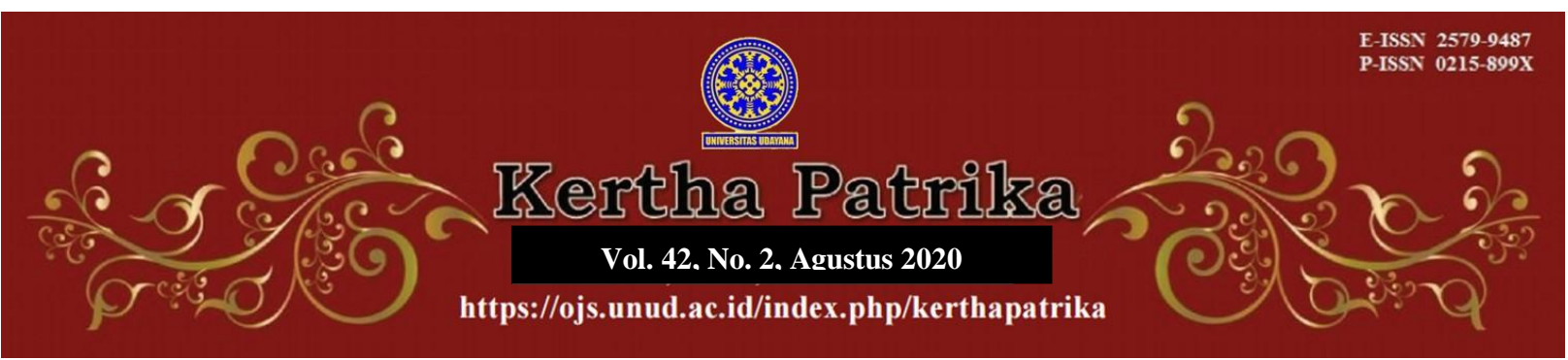

\title{
Potensi Pendaftaran Indikasi Geografis Kopi Lereng Semeru oleh Pemerintah Daerah dalam Menghadapi ASEAN Economic Community
}

\author{
Khoirul Hidayah, ${ }^{1}$ Iffaty Nasyi'ah ${ }^{2}$ \\ 1Fakultas Syariah Universitas Islam Negeri Maulana Malik Ibrahim Malang, \\ E-mail: khoirulhidayah55@gmail.com \\ ${ }^{2}$ Fakultas Syariah Universitas Islam Negeri Maulana Malik Ibrahim Malang, \\ E-mail: iffaty.nasyiah@gmail.com
}

\begin{tabular}{l}
\hline Info Artikel \\
\hline Masuk : 9 Januari 2020 \\
Diterima : 20 April 2020 \\
Terbit : 31 Agustus 2020 \\
Keywords : \\
Geographic Indication;Local \\
Government; ASEAN Economic \\
Community \\
\\
Corresponding Author: \\
Khoirul Hidayah,E-mail: \\
khoirulhidayah55@gmail.com \\
Community \\
Indikasi Geografis; Pemerintah \\
Daerah; ASEAN Economic \\
\end{tabular}

\begin{abstract} market value. Malang Regency has coffee products planted in the hillside of Semeru Mountain that has been exported to abroad. However, to date, this regency has yet to register even one single superior agricultural product that has a geographical feature. This article discusses the effort of Malang Regency government (the Government) to give legal protection in the form of Geographical Indication (GI) registration for coffee farmers in the Semeru hillside to challenge ASEAN Economic Community free trade and how the attempt is observed fromjustice perspective. This is a juridical sociological study with a qualitative approach. The government in 2015 proposed GI registration budget for Robusta Coffee's Semeru hillside to the regent and were not yet agreed by Regional House of Representative in Malang Regency. Creativity and local products surely need legal protection from the local government. The legal protection from the local government is to give thejustice of traditional society. To realize justice, the government must give happiness and benefit to society throughIG recognition in the global market.
\end{abstract}




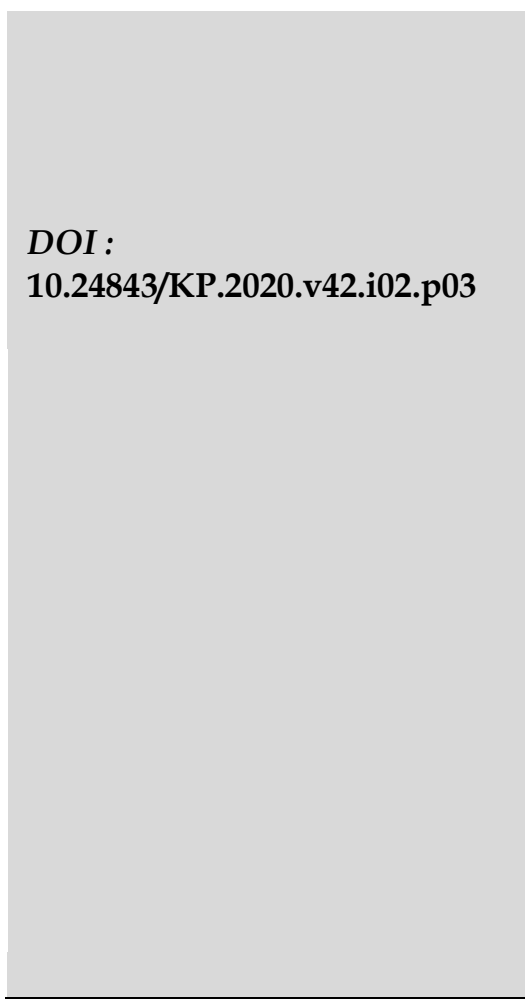

pendaftaran IG bagi masyarakat petani kopi lereng semeru dalam menghadapi pasar bebas ASEAN Economic Community dan bagaimanakah upaya tersebut ditinjau dalam perspektif keadilan. Artikel ini merupakan penelitian yuridis sosiologis dengan pendekatankualitatif. Upaya yang sudah dilakukan oleh Pemerintah Daerah Kabupaten Malang dalam memberikan perlindungan hukum bagi masyarakat petani lokal adalah pada tahun 2015mengajukan penganggaran pendaftaran IG Kopi Robusta lereng semeru kepada Bupati, namun belum mendapatkan persetujuan dari Dewan Perwakilan Rakyat Daerah (DPRD) Kabupaten Malang.Upaya pemerintah daerah dalam memberikan perlindungan kopi lereng Semeru sebagai kekayaan masyarakat tradisional melalui IG merupakan upaya memberikan keadilan bagi masyarakat lokal. Keadilan dapatterwujud denganmemberikan kebahagiaan masyarakat lokal melalui diakuinya kopi lereng semeru sebagai IG dan juga mampu memberikan kemanfaatan yaitu semakin dikenalnya kopi lereng semeru di pasar global.

\section{Pendahuluan}

Dalam menghadapi ASEAN Economic Community (AEC) 2015 seluruh lini termasuk produk pertanian harus memperhatikan 3 hal penting yaitu pertama, peningkatan daya saing (peningkatan produktifitas, distribusi, infrastruktur, perbankan, dan efisiensi regulasi), kedua, pengamanan pasar domestik (seperti lebih mencintai produk lokal), dan ketiga penguatan ekspor dengan memperhatikan $3 \mathrm{~K}$ (kualitas, kuantitas dan kontinyuitas). ${ }^{1}$

Keberadaan AEC memang membuka peluang pasar bagi produksi pertanian lokal di Indonesia, tetapi sebaliknya juga merupakan ancaman terhadap dilakukannyapengakuan atas produksi khas masyarakat lokal oleh pihak asing. Beberapa kasus yang sudah pernah terjadi yaitu pengakuan atas kopi Gayo dan kopi Toraja oleh beberapa negara telah didaftarkan oleh perusahaan di Eropa dengan merek dagang "Gayo Mountain Coffee" dan telah melakukan pelarangan terhadap salah satu eksportir kopi Indonesia yaitu CV. Arvis Sanada, salah satu perusahaan eksportir kopi arabika asal Gayo Aceh. Perusahaan Indonesia tersebut dilarang mengekspor kopi ke daratan Eropa dengan menggunakan kata Gayo dalam kemasannya, padahal biji kopi tersebut adalah berasal dari Gayo Aceh. Hal yang sama juga terjadi terhadap kopi Toraja. Key Coffee Inc. Corporation dari Jepang telah mendaftarkan Merek "Toarco Toraja". Merek tersebut selain menampilkan kata "Toraja" juga rumah adat Toraja sebagai latar merek. Pelarangan terhadap kopi Toraja oleh Jepang perlu diwaspadai

\footnotetext{
${ }^{1}$ Mandagi, S. (5 - 8 Maret 2013). Pertemuan Koordinasi Pelayanan Informasi Pasar (PIP) Tingkat Nasional di Manado
} 
sebagaimana yang pernah terjadi di Eropa. ${ }^{2} \mathrm{WIPO}$ memberikan definisi Indikasi Geografis(selanjutnya disebut IG), yaitu: ${ }^{3}$

"A Geographical Indication is a sign used ongoods that have specific geographical origin andpossess qualities or a reputation that are due to thatplace of origin. Most commonly, a geographicalindications consists of the name of the place of originof the goods. Agricultural products typically havequalities that derive from their place of productionand are influenced by specific local factors, such asclimate and soil".

Fenomena ini terjadi karena produk tersebut belum terdaftar dalam perlindungan indikasi geografis di Indonesia dan tidak memiliki perlindungan hukum di negaranegara tersebut, sehingga produk-produk tersebut perlu didaftarkan dalam perlindungan hukum indikasi geografis.

IG merupakan bentuk perlindungan hukum terhadap nama asal barang yang diatur di dalam Undang-Undang No. 15 Tahun 2001 tentang Merek dan Peraturan Pemerintah No. 51 Tahun 2007 tentang Indikasi Geografis, dan telah diperbarui melalui UU No. 20 tahun 2016 tentang Merek dan Indikasi Geografis. Maksud perlindungan hukum ini adalah bahwa pihak yang tidak berhak, dilarang menggunakan indikasi geografis jika penggunaan tersebut cenderung dapat menipu masyarakat mengenai daerah asal produk. Indikasi geografis juga mampu meningkatkan nilai tambah sebuah produk, sehingga diharapkan mampu memberikan keuntungan komersial/bisnis yang tinggi bagi produk yang dihasilkan oleh masyarakat lokal.

Indonesia adalah negara yang kaya akan keanekaragaman hayati yang dipengaruhi oleh faktor geografis yang berbeda. Sebagai contohnya adalah beras dan kopi, Indonesia memiliki berbagai macam jenis yang dipengaruhi oleh kondisi alam yang berbeda, sehingga menghasilkan jenis dan kualitas yang berbeda antara daerah satu dengan daerah yang lainnya, sebagaimana seperti kopi Gayo, kopi Kintamani dan beras Adan Krayan yang memiliki ciri khas yang berbeda berdasarkan asal daerah dan keadaan geografis.

Kabupaten Malang adalah salah satu daerah di Jawa Timur yang mempunyai banyak potensi sumber daya alam yang dapat diunggulkan. Salah satunya adalah produk pertanian. Produk pertanian yang dihasilkan oleh masyarakat kabupaten Malang mempunyai banyak ragamnya, seperti kopi, beras, sayur-sayuran dan buah-buahan. Dalam menghadapi pasar bebas khususnya AEC, tentunya petani membutuhkan bantuan dalam bentuk pendampingan dan pemberdayaan guna meningkatkan kualitas produk ataupun bantuan dalam memperluas pasar di luar negeri.

Kopi adalah salah satu produk pertanian yang mempunyai peluang pangsa pasar di luar negeri. Kabupaten Malang memiliki produk kopi yang ditanam di lereng Semeru (seperti Kecamatan Dampit dan Sumbermanjing) yang telah diekspor ke luar negeri. ${ }^{4}$ Berdasarkan data dari Direktorat JendralKekayaan Intelektual Kemenkumham, sejak tahun 2007 (sejak dikeluarkannya Peraturan Pemerintah No. 51 Tahun 2007 tentang

\footnotetext{
2 Septiono, S. (2009). Perlindungan Indikasi Geografisdan Potensi Indikasi Geografis Indonesia. Http:// Dirjen HKI. go.id. p. 1

${ }^{3}$ http://www.wipo.int/geo_indications/en/about.html

${ }^{4}$ http:/ / www. Malangkab.go.id. Kopi Asal Kabupaten Malang Jasi Idola Dunia
} 
Indikasi Geografis) sampai pada tahun 2014, jumlah IG yang terdaftar masih berjumlah 30 produk pada tahun 2015, dan sekarang per Oktober 2019 sudah bertambah menjadi 65 Indikasi Geografis. Kabupaten Malang sampai pada saat ini belum mendaftarkan satupun produk unggulan pertanian yang memiliki ciri geografis. Padahal Kabupaten mempunyai beberapa produk pertanian unggulan yang mempunyai nilai jual di pasar luar negeri seperti kopi. Hal inilah yang menjadi latar belakang pentingnya dilakukan penelitian tentang pendaftaran IG terhadap produk unggulan pertanian di Kabupaten Malang dalam rangka menghadapi AEC 2015.Persoalan yang akan dikaji adalah upaya apakah yang sudah dilakukan oleh pemerintah daerah Kabupaten Malang dalam memberikan perlindungan hukum dalam bentuk pendaftaran IG bagi masyarakat petani kopi lereng semeru dalam menghadapi pasar bebas AECdan bagaimanakah upaya tersebut ditinjau dalam perspektif keadilan.

Penelitian IG sebelumnya sudah pernah beberapa kali dilakukan. Pada tahun 2017, Ketut Ardana melakukan penelitian yang berjudul "Kinerja Kelembagaan Perlindungan Indikasi Geografis Kopi Kintamani." 5 Kemudian terdapat pula penelitianTomy Pasca Rifai berjudul "Kesiapan Undang-Undang Nomor 20 Tahun 2016 Tentang Merek Dan Indikasi Geografis dalam Menghadapi Masyarakat Ekonomi ASEAN"(2018), ${ }^{6}$ tahun 2017 oleh Toebagus Galang Windi Pratama and Kholis Roisah, Potensi Pendaftaran Kretek Sebagai Indikasi Geografis Kabupaten Kudus",7penelitian oleh Nizar Apriansyah, Tahun 2018, “Perlindungan Indikasi Geografis Dalam Rangka Mendorong Perekonomian Daerah, 8 selanjutnya M. Rendi Aridhayandi (2017) , "Focus Group Discussion Mengenai Pemahaman Perubahan Aturan Hukum Indikasi Geografis Bagi Masyarakat Pelestari Padi Pandanwangi Cianjur (MP3C) Sebagai Pemegang Hak Indikasi Geografis Terdaftar ${ }^{9}$ dan penelitian oleh Imam Lukito (2019), "Peran Pemerintah Daerah Dalam Mendorong Potensi Indikasi Geografis (Studi Pada Provinsi Kepulauan Riau). ${ }^{10 S e c a r a}$ keseluruhan artikel sebelumnya belum ada yang melakukan penelitian terkait potensi pendaftaran IG kopi lereng semeru di Kabupaten Malang dalam menghadapi ASEAN Economic Community.

\section{Metode Penelitian}

${ }^{5}$ Ardana, K. (2017). Kinerja Kelembagaan Perlindungan Indikasi Geografis Kopi Kintamani,Agricore, Jurnal Agribisnis dan Sosial Ekonomi Pertanian, 2 (1), 205-290.

6 Rifai, T.P. (2017). Kesiapan Undang-Undang Nomor 20 Tahun 2016 Tentang Merek DanIndikasi Geografis Dalam Menghadapi Masyarakat Ekonomi Asean. Fiat Justisia, 10 (4), 733-776. doi.org/10.25041/ fiatjustisia.v10no4.809.

7Pratama, T.G.W. dan Roisah, K. (2017). Potensi Pendaftaran Kretek SebagaiIndikasi Geografis Kabupaten Kudus. Law Reform, 12 (2), p. 288-304. doi.org/10.14710/ lr.v12i2.15881.

${ }^{8}$ Apriansyah, N.. (2018). Perlindungan Indikasi Geografis Dalam Rangka Mendorong PerekonomianDaerah. Jurnal Penelitian Hukum De Jure, 18 (4), 525-542. doi.org/10.30641/dejure.2018.v18.525-542.

${ }^{9}$ Aridhayandi, M. R. (2017). Focus Group Discussion Mengenai Pemahaman Perubahan Aturan Hukum Indikasi Geografis Bagi Masyarakat Pelestari Padi Pandanwangi Cianjur (Mp3c) Sebagai Pemegang Hak Indikasi Geografis Terdaftar. Journal Of Empowerment UniversitasSuryakancana, 1 (2), 87-102. doi.org/10.35194/je.v1i2.200

10Lukito, I. (2018). Peran Pemerintah Daerah Dalam Mendorong Potensi Indikasi Geografis (Studi Pada Provinsi Kepulauan Riau). Jurnal Ilmiah Kebijakan Hukum, 12 (3), 313-330. doi.org/10.30641/ kebijakan.2018.v12.313-330. 
Jenis penelitian yang akan digunakan adalah jenis penelitian empiris dengan pendekatan yuridis sosiologis, yaitu dengan mendeskripsikan peran Pemda Kabupaten Malang dalam membantu petani untuk mendapatkan perlindungan hukum atas produk lokal petani dalam menghadapi pasar bebas AEC dan menganalisanya dengan menggunakan Undang-Undang No. 20 Tahun 2016 tentang Merek dan Indikasi Geografis dan Peraturan Pemerintah No. 51 Tahun 2007 tentang Indikasi Geografis dan teori keadilan. Data primer dalam penelitian ini adalah data yang diambil langsung dari hasil wawancara di Disperindag Kabupaten Malang, Dinas Pertanian Kabupaten Malang, Kemenkumham Kanwil Surabaya dan kelompok petani di Kabupaten Malang. Data sekunder adalah data yang dapat mendukung data primer yaitu dalam bentuk peraturan perundang-undangan yang terkait dengan indikasi geografis yaitu meliputi UU No. 20 Tahun 2016 tentang Merek dan indikasi geografis, Peraturan Pemerintah No. 51 Tahun 2007 tentang Indikasi Geografis. Data sekunder diperoleh dengan dokumentasi dan juga penelusuran literatur beberapa buku atau jurnal yang terkait dengan indikasi geografis. Teknik pengumpulan data dilakukan melalui wawancara dan dokumentasi. Data yang diperoleh melalui wawancara mendalam akan dianalisis dengan menggunakan metode deskriptif kualitatif yakni dengan melakukan klasifikasi, identifikasi dan selanjutnya analisis dilakukan dengan menjelaskan hubungan-hubungan antara hasil wawancara dengan kebijakan pemerintah melalui Undang-Undang No. 20 Tahun 2016 dan Peraturan Pemerintah No. 51 Tahun 2007 tentang Indikasi Geografis dan juga teori keadilan.

\section{Hasil Dan Pembahasan}

\subsection{Pengaturan Indikasi Geografis}

Indikasi geografis (IG) merupakan tanda yang digunakan untuk produk yang mempunyai asal geografis spesifik dan mempunyai kualitas atau reputasi yang berkaitan dengan asalnya. Pada umumnya indikasi geografis terdiri dari nama produk yang diikuti dengan nama daerah atau tempat asal produk. WIPO mendefinisikan IG sebagai berikut:

"A Geographical Indication is a sign used ongoods that have specific geographical origin andpossess qualities or a reputation that are due to thatplace of origin. Most commonly, a geographicalindications consists of the name of the place of originof the goods. Agricultural products typically havequalities that derive from their place of productionand are influence by specific local factors, such asclimate and soil".

Berdasarkan pengertian di atas, maka berikut ini adalah unsur pokok IG berupa: (1) Tanda yang diambil dari nama daerah yang merupakan ciri khas suatu produk atau barang yang diperdagangkan. (2) Tanda yang menunjukkan kualitas atau reputasi produk atau barang yang bersangkutan. (3) Kualitas barang tersebut dipengaruhi oleh alam, cuaca dan tanah di daerahyang bersangkutan.

Perlindungan atasIG juga diatur dalam ketentuan Pasal 22 sampai denganPasal24Perjanjian TRIPs(TradeRelated ofIntelectual PropertyRights). TRIPsmerupakan perjanjian multilateral yang paling lengkap mengatur tentang Hak Kekayaan Intelektual termasuk di dalamnya pengaturan tentang Indikasi geografis. 
Pasal 22.1 memberikan definisi tentang IG yaitu "Indikasi geografis berdasarkan persetujuan ini adalah tanda yang mengindentifikasikan suatu wilayah negara anggota, atau kawasan atau daerah didalam wilayah tersebut sebagai asal baran, dimana reputasi, kualitas dan karakteristik barang yang bersangkutan sangat ditentukan oleh faktor geografis tersebut." Pasal 22 mengatur tentang sarana hukum bagi perlindungan semua produk indikasi geografis dimana dapat dijelaskan bahwa IG dilindungi sebagai upaya menghindari terjadinya penyesatan publik dan mencegah persaingan curang.

Indikasi geografis yang diatur di dalam pasal 56 Undang-Undang No. 20 Tahun 2016 tentang Merek (UUM) merupakan peraturan yang masih bersifat umum. Guna melaksanakan pasal tersebut sebagaimana tercantum dalam ayat 9 maka pemerintah mengeluarkan Peraturan Pemerintah No. 51 Tahun 2007 tentang Indikasi Geografis. Pengertian indikasi geografis sebagaimana disebutkan di dalam pasal 56 UUM dan pasal 1(1) PP No. 51/2007 adalah suatu tanda yang menunjukkan daerah asal suatu barang, yang karena faktor lingkungan geografis termasuk faktor alam, faktor manusia, atau kombinasi dari kedua faktor tersebut, memberikan ciri dan kualitas tertentu pada barang yang dihasilkan.

Menurut penjelasan Pasal 56, IG adalah "suatu indikasi atau identitas dari suatu barang yang berasal dari suatu tempat, daerah atau wilayah tertentu yang menunjukkan adanya kualitas, reputasi dan karakteristik termasuk faktor alam dan faktor manusia yang dijadikan atribut dari barang tersebut. Tanda yang digunakan sebagai indikasi geografis dapat berupa etiket atau label yang dilekatkan pada barang yang dihasilkan. Tanda tersebut dapat berupa nama tempat, daerah, atau wilayah, kata, gambar, huruf, atau kombinasi dari unsur-unsur tersebut. Pengertian nama tempat dapat berasal dari nama yang tertera dalam peta geografis atau nama yang karena pemakaian secara terus-menerus sehingga dikenal sebagai nama tempat asal barang yang bersangkutan. Perlindungan IG meliputi barang-barang yang dihasilkan oleh alam, barang hasil pertanian, hasil kerajinan tangan; atau hasil industri tertentu lainnya."

Indikasi geografis pada UU Merek yang lama mengatur secara umum dan diatur melalui secara khusus dalam Peraturan Pemerintah No. 51 Tahun 2007 tentang Indikasi Geografis. Namun UUM yang baru telah mengatur secara khusus di dalam pasal 53-71, dan nama UU nya pun juga berubah yaitu UU tentang Merek dan Indikasi Geografis. ${ }^{11}$

Indikasi geografis menurut pasal 53 (3) Undang No. 20 Tahun 2016 mendapat perlindungan setelah terdaftar atas dasar permohonan yang diajukan oleh:

“(1) lembaga yang mewakili masyarakat di kawasan geografis tertentu yang mengusahakan suatu barang dan/atau produk berupasumber daya alam, barang kerajinan tanganatauhasil industri.

(2) pemerintah daerah provinsi atau kabupaten/kota."

Permohonan pendaftaran indikasi geografis menurut pasal 56 UU Merek akan ditolak oleh Direktorat Jenderal apabila tanda tersebut bertentangan dengan moralitas agama,

${ }^{11}$ Hidayah, K. (2017). Hukum Hak Kekayaan Intelektual. Malang: Setara Press, p. 62 
kesusilaan, ketertiban umum, dan dapat memperdayakan atau menyesatkan masyarakat mengenai sifat, ciri, kualitas, asal sumber, proses pembuatan, dan/atau kegunaannya.

\subsection{Kopi Robusta Lereng Semeru}

Hasil perkebunan Kabupaten Malang meliputi kelapa, kopi jenis robusta, kopi arabica, cengkeh, kakao, panili, kayu manis, teh, jambu mete dan merica. Hasil perkebunan yang mempunyai nilai jual di pasal global dan berpeluang mendapatkan perlindungan IG adalah kopi robusta semeru yang berada di lereng Gunung Semeru. Wilayah penghasil kopi ini meliputi Kecamatan Ampelgading, Kecamatan Sumbermanjing Wetan, Kecamatan Tirtoyudo dan Kecamatan Dampit ${ }^{12}$

Hasil wawancara yang dilakukan terhadap Kholida, Kepala Seksi Produksi Perkebunan Dinas Tanaman Pangan, Hortikultura dan Perkebunan menyatakan bahwa:

“Kopi Robusta Dampit adalah produk unggulan Kabupaten Malang, karena sudah diekspor. Masyarakat petani kopi melalui kelompok tani telah dibina dan didampingi oleh PT. Asal Jaya yang sudah melakukan ekspor kopi Dampit ke beberapa negara seperti Jepang, Belgia dalam bentuk Green Bean. Perusahaan tersebut telah membantu para petani untuk menghasilkan kopi berkualitas internasional." 13

Sejarah kopi Robusta lereng Semeru adalah sejak jaman kolonial Belanda yaitu pada tahun 1871, telah berdiri perkebunan kopi seluas 525 Hektar di Desa Bumirejo dan Sukodono Kecamatan Dampit. Tanaman kopi pada saat itu merupakan komoditas tanaman yang dikelola oleh perusahaan perkebunan milik Belanda. Varietas kopi robusta dengan beberapa klon sampai sekaraang berbagai klon unggul baik lokalmaupun hasil penelitian SP BP42, BP358, BP 409, tugu sari, dan lain-lainnya. Cita rasa kopi robusta Dampit mempunyai rasa yang khas, bentuk biji bulat dan lebih besar, kafein tinggi, keasaman rendah, tumbuh di ketinggian $1000 \mathrm{mdpl}$, dan produksi per hektar mencapai 1,5 ton. ${ }^{14}$ Kawasan Dampit bagian selatan sebelumnya adalah hutan. Belanda yang mengawali membuka dan membangun perkebunan di daerah tersebut. Letak geografis yang strategis berada diantara lereng Gunung Semeru dan laut pantai selatan membuat daerah tersebut cocok dijadikan sentra kebun kopi dengan aroma dan cita rasa yang khas. Seiring waktu, kebun kopi meluas berkembang ke wilayah di sekitarnya.

Kesadaran petani terhadap kualitas kopi yang memiliki aroma cita rasa yang khas dan berstandart internasional adalah tidak terlepas dari peran PT. Asal Jaya yang melakukan ekspor kopi Dampit ke 45 negara, seperti Eropa Timur, Eropa Tengah,

\footnotetext{
${ }^{12}$ Widodo, Budi. Kasi Produksi Pembenihan dan Perlindungan Hortikultura. (Sabtu, 29 September 2019). Hasil Wawancara.

${ }^{13}$ Kholida, Kasi Produksi Perkebunan Dinas Tanaman Pangan, Hortikultura dan Perkebunan. (Senin, 8 Juli 2019). Hasil Wawancara.

14Kholida, Kasi Produksi Perkebunan Dinas Tanaman Pangan, Hortikultura dan Perkebunan. (Senin, 8 Juli 2019). Hasil Wawancara.
} 
Timur Tengah, Jepang dan Amerika. Branding Kopi Dampit dengan aroma dan cita rasa khasnya dimulai pada tahun 2015. Hal tersebut ditandai dengan berdirinya Asosiasi Sridonoretno. Nama Sridonoretno merupakan gabungan dari nama tiga desa yang berada di Kecamatan Dampit bagian selatan, yaitu Desa Srimulyo, Desa Sukodono dan Desa Baturetno. ${ }^{15}$

Petani dalam Asosiasi Sridonoretno mulai belajar cara memperlakukan kopi yang baik, yaitu mulai dari proses pemberdayaan tanaman kopi, proses panen dan proses pascapanen. Melalui upaya tersebut, aroma dan cita rasa kopi Dampit memiliki ciri khas yang kuat. Aroma dan cita rasa khas yang terdapat di dalam biji kopi disebabkan oleh kondisi geografis dan tanah Dampit. Nilai ekspor kopi meningkat, sebagaimna dijelaskan Kholida, Kepala Seksi Produksi Perkebunan Dinas Tanaman Pangan, Hortikultura dan Perkebunan menyatakan bahwa:

"Nilai produksi kopi meningkat, total Produksi kopi robusta tahun 2017 adalah sebesar 10.141 ton dan tahun 2018 mengalami peningkatan sebesar 10.284 ton". ${ }^{16}$

Data di atas menunjukkan bahwa nilai produksi kopi semakin meningkat, oleh sebab itu untuk semakin meningkatkan nilai ekonomi kopi robusta lereng semeru dibutuhkan pengakuan pasar melalui identitas produk di pasar nasional atau global seperti pendaftaran IG.

\subsection{Upaya Pemerintah Daerah Kabupaten Malang Dalam Memberikan Perlindungan Hukum Bagi Masyarakat Petani Lokal Dalam Menghadapi Pasar Bebas AEC (ASEAN Economic Community)}

Pendaftaran IG merupakan bentuk perlindungan hukum hasil produksi masyarakat lokal daerah tertentu yang memiliki ciri indikasi geografis yang diberikan pemerintah memeluai UU No. 20 tahun 2016 tentang Merek dan IG. Secara normatif, pemerintah telah mengaturnya sebagai upaya prefentif perlindungan hukum bagi masyarakat lokal. Menurut Lawrence Meir Friedman (Lawrence M. Friedman) dalam teori sistem hukum yang dibuatnya, efektifitas sebuah sistem hukum (legal system) untuk mewujudkan tujuan hukumnya dapat ditinjau melalui tiga unsur utama, yaitu: ${ }^{17}$

a. Isi hukum (legal substance)

b. Struktur hukum (legal structure)

c. Budaya hukum (legal culture)

Pertama, isi hukum (legal substance). Lawrence M. Friedman dalam teori sistem hukumnya menyatakan bahwa aspek ini merupakan aspek substansial yang menentukan bisa tidaknya isi hukum dilaksanakan. Salah satu pengaruhnya adalah diberlakukannya asas legalitas. Substansi hukum menurut Friedman adalah"Another aspect of the legal system is its substance. By this meant the actual rules, norm, and behavior patterns of people inside the system ... the stress here is on living law, not just rules in law books".

15 Supriono. Ketua Poktan Sumber Tani Desa Srimulyo, Dampit. (Jumat, 30 Agustus 2019). Hasil Wawancara.

${ }^{16}$ Kholida, Kasi Produksi Perkebunan Dinas Tanaman Pangan, Hortikultura dan Perkebunan. (Senin, 8 Juli 2019). Hasil Wawancara.

17Friedman, L, M. (2013). Sistem Hukum Perspektif Ilmu Sosial, The Legal System: A Sosial S cience Perspective. Bandung: Nusamedia, p. 12-19 
Ketentuan IG yang diatur melalui article 22-24 Trade Related Intellectual Property Rights (TRIPs) telah mewajibkan Indonesia untuk mengatur perlindungan IG bagi masyarakat lokal dan telah secara lengkap diatur di dalam pasal 53-71 UU Merek dan Indikasi Geografis. Pasal tersebut telah mengatur mulai proses pendaftaran IG sampai pada pembinaan dan pengawasan IG. Peraturan pelaksana untuk IG sejak tahun 2016 belum dikeluarkan peraturan baru sehingga sampai saat ini masih tetap menggunakan Peraturan Pemerintah No. 51 Tahun 2007 tentang Indikasi Geografis.Perlindungan atas indikasi geografis yang diatur dalam ketentuan pasal 22 -24Perjanjian TRIPs. TRIPs(Trade Related of Intelectual Propherty Rights) merupakan perjanjian multilateral yang paling lengkap mengatur tentang Hak Kekayaan Intelektual termasuk di dalamnya pengaturan tentang Indikasi geografis. Pasal 22.1 memberikan definisi tentang Indikasi geografis yaitu: 18

"Indikasi geografis berdasarkan persetujuan ini adalah, tanda yang mengindentifikasikan suatu wilayah negara anggota, atau kawasan atau daerah didalam wilayah tersebut sebagai asal baran, dimana reputasi, kualitas dan karakteristik barang yang bersangkutan sangat ditentukan oleh faktor geografis tersebut."

Pasal 22 mengatur tentang sarana hukum bagi perlindungan semua produk indikasi geografis dimana dapat dijelaskan bahwa indikasi geografis dilindungi sebagai upaya menghindari terjadinya penyesatan publik dan mencegah persaingan curang.

Indikasi geografis yang diatur di dalam pasal 56 Undang-Undang No. 20 Tahun 2016 tentang Merek (UUM) merupakan peraturan yang masih bersifat umum. Guna melaksanakan pasal tersebut sebagaimana tercantum dalam ayat 9 maka pemerintah mengeluarkan Peraturan Pemerintah No. 51 Tahun 2007 tentang Indikasi Geografis. Pengertian indikasi geografis sebagaimana disebutkan di dalam pasal 56 UUM dan pasal 1(1) PP No. 51/2007 adalah suatu tanda yang menunjukkan daerah asal suatu barang, yang karena faktor lingkungan geografis termasuk faktor alam, faktor manusia, atau kombinasi dari kedua faktor tersebut, memberikan ciri dan kualitas tertentu pada barang yang dihasilkan.

Menurut penjelasan pasal 56, Indikasi geografis adalah suatu indikasi atau identitas dari suatu barang yang berasal dari suatu tempat, daerah atau wilayah tertentu yang menunjukkan adanya kualitas, reputasi dan karakteristik termasuk faktor alam dan faktor manusia yang dijadikan atribut dari barang tersebut. Tanda yang digunakan sebagai indikasi geografis dapat berupa etiket atau label yang dilekatkan pada barang yang dihasilkan. Tanda tersebut dapat berupa nama tempat, daerah, atau wilayah, kata, gambar, huruf, atau kombinasi dari unsur-unsur tersebut. Pengertian nama tempat dapat berasal dari nama yang tertera dalam peta geografis atau nama yang karena pemakaian secara terus-menerus sehingga dikenal sebagai nama tempat asal barang yang bersangkutan. Perlindungan indikasi geografis meliputi barang-barang yang dihasilkan oleh alam, barang hasil pertanian, hasil kerajinan tangan; atau hasil industri tertentu lainnya.

Indikasi geografis pada UU Merek yang lama mengatur secara umum dan diatur melalui secara khusus dalam Peraturan Pemerintah No. 51 Tahun 2007 tentang

18 Mahkamah Agung RI. (1998). GATT, TRIPS dan Kekayaan Intelektual. 
Indikasi Geografis. Namun UUM yang baru telah mengatur secara khusus di dalam pasal 53-71, dan nama UU nya pun juga berubah yaitu UU tentang Merek dan Indikasi Geografis.Pengertian indikasi geografis sebagaimana disebutkan di dalam pasal 1 UUM adalah suatu tanda yang menunjukkan daerah asal suatu barang, yang karena faktor lingkungan geografis termasuk faktor alam, faktor manusia, atau kombinasi dari kedua faktor tersebut, memberikan reputasi, kualitas dan karakteristik tertentu pada barang dan atau produk yang dihasilkan. Tanda yang digunakan sebagai indikasi geografis dapat berupa etiket atau label yang dilekatkan pada barang yang dihasilkan. Tanda tersebut dapat berupa nama tempat, daerah, atau wilayah, kata, gambar, huruf, atau kombinasi dari unsur-unsur tersebut. Pengertian nama tempat dapat berasal dari nama yang tertera dalam peta geografis atau nama yang karena pemakaian secara terus-menerus sehingga dikenal sebagai nama tempat asal barang yang bersangkutan. Perlindungan indikasi geografis meliputi barang-barang yang dihasilkan oleh alam, barang hasil pertanian, hasil kerajinan tangan; atau hasil industri tertentu lainnya (olahan manusia dari barang mentah menjadi barang jadi seperti tenun Sikka, tenun Grinsing (pasal 53 ayat 3).

Kedua, struktur hukum (legal structure). Lawrence menyatakan bahwa sistem struktural ini yang menentukan bisa tidaknya hukum itu dilaksanakan dengan baik atau tidak. Friedman menjelaskan bahwa: ${ }^{19}$

"To begin with the legal system has the structure of a legal system consist of elements of this kind: the number and size of courts; their jurisdiction ... structure also means how the legislature is organized. . . what procedure the police department follow, and so on. Structure, in way, is a kind of cross section of the legal system . . a kind of still photograph with freezes the action."

Struktur hukum terkait IG diatur dalam pasal 70 dan 71 UU No. 20 Tahun 2016 tentang Merek dan Indikasi Geografis. Struktur hukum yang diberikan kewenangan melakukan pembinaan dan pengawasan IG adalah pemerintah daerah dan pemerintah pusat. Upaya pemerintah daerah dalam melakukan pembinaan sangat penting sekali. Pemerintah daerah Kabupaten Malang yang terkait dengan IG dan sudah melakukan upaya pembinaan adalah salah satunya Dinas Tanaman Pangan, Hortikultura dan Perkebunan.

Berdasarkan hasil wawancara terhadap beberapa informan yang berada di Dinas Tanaman Pangan, Hortikultura dan Perkebunan, upaya yang sudah dilakukan dalam memberikan perlindungan hukum bagi petani masyarakat lokal adalah:20

1. Pada tahun 2015 telah dibentuk Asosiasi Petani Kopi Robusta Kabupaten Malang yang meliputi wilayah Amstirdam yaitu Kecamatan Ampelgading, Sumbermanjing Wetan, Tirtoyudo, dan Dampit.Asosiasi yang sudah terbentuk diberikan pembinaan khusus oleh dinas. Pembentukan asosiasi di atas merupakan bagian dari upaya pemerintah daerah untuk menyiapkan adanya peran faktor manusia untk menentukan karakteristik IG sebagai syarat proses pendaftaran IG.

\footnotetext{
${ }^{19}$ Friedman, L, M. (2001). American Law An Introduction, Second Edition. Jakarta: Tatanusa, p. 4-5

${ }^{20}$ Widodo, Budi. Kasi Produksi Pembenihan dan Perlindungan Hortikultura. (Sabtu, 29 September 2019). Hasil Wawancara.
} 
2. Pada tahun 2015 telah membuat nama IG untuk kopi robusta di bawah lereng gunung Semeru dengan nama "Kopi Robusta Lereng Semeru".

3. Tahun 2015 telah membuat batas kawasan perlindungan IG untuk kopi robusta lereng semeru yang meliputi Kabupaten Malang, Kabupaten Pasuruan, Kabupaten Probolinggo dan Kabupaten Lumajang.

4. Peningkatan mutu produk perkebunan kopi melalui teknologi budidaya yang baik dan pasca panen dalam bentuk pelatihan GAP (Good Agriculture Practices) dan GHP (Good Handling Practices). Pelatihan GAP untuk memberikan skill cara budidaya menanam kopi yang baik. Sedangkan pelatihan GHP bertujuan untuk memberikan skill penanganan pasca panen dan pengolahan hasil perkebunan.

5. Mengajukan permohonan pendaftaran IG Kopi Robusta Dampit kepada Propinsi Jawa Timur pada tahun 2015 untuk dapat pembiayaan pendaftaran IG.Hasil wawancara dengan Kepala Seksi Produksi Perkebunan Dinas Pertanian Jawa Timur menyatakan bahwa Propinsi tidak menyediakan anggaran pendaftaran IG, semua murni dibiayai Kabupaten. ${ }^{21}$ Informasi yang diberikan oleh pihak Kemenkumham Kanwil Surabaya menyatakanbahwa sampai pada tahun 2019, belum pernah menerima pengajuan IG dari Kabupaten Malang. ${ }^{22}$

Berdasarkan penjelasan tersebut, sepertinya Pemda Kabupaten Malang belum mampu menyiapkan anggaran untuk hal tersebut. Diperlukan niat kuat dari Pemda untuk membantu masyarakat lokal dalam mendaftarkan IG.Persoalan anggaran telah terjawab, bahwa anggaran proses pengajuan IG adalah menjadi beban masing-masing Kabupaten. Hal ini harus menjadi perhatian Pemda Kabupaten Malang untuk bisa memberikan perhatian terhadap masyarakat petani lokal untuk mendapatkan identitas produk lokal petani yang berdaya saing. Dinas Perkebunan Propinsi Jawa Timur dalam Rencana Strategis 2014-2019 menjelaskan bahwa adanya fasilitasi terhadap terbentuknya perlindungan kawasan komoditi yang memiliki kekhasan tertentu, untuk mendapatkan sertifikat indikasi geografis (IG). Namun di dalam implementasinya, dukungan yang diberikan pemda propinsi adalah hanya dalam bentuk sosialisasi saja, untuk pendaftaran IG diserahkan kepada masing-masing pemerintah daerah atau kabupaten.

6. Mengajukan kepada DPRD Kabupaten Malang untuk dapat menganggarkan pendaftaran IG pada tahun 2015, namun tidak disetujui oleh anggota Dewan. Dewan tidak menyetujui sebagai skala prioritas anggaran, karena kopi robusta lereng semeru berada di wilayah 4 kabupaten yaitu Malang, Pasuruan, Probolinggo dan Lumajang. ${ }^{23}$ Penyiapan IG oleh Dinas Tanaman Pangan, Hortikultura dan Perkebunan dengan dibantu PT. Asal Jaya telah melakukan pembinaan terhadap kelompok tani di Dampit. Sosialisasi dan pembinaan bertujuan untuk membuat penyamaan ciri, karakteristik dan kualitas kopi

${ }^{21}$ Asma. Kasi Produksi Perkebunan Dinas Pertanian Jawa Timur. (Senin, 2 September 2019). Hasil Wawancara

22 Witantra, Pahlevi. Kasubid Pelayanan Kekayaan Intelektual, Kemenkumham Wilayah Surabaya. (Selasa, 23 Juli 2019). Hasil Wawancara.

${ }^{23}$ Widodo, Budi. Kasi Produksi Pembenihan dan Perlindungan Hortikultura. (Sabtu, 29 September 2019). Hasil Wawancara. 
Dampit. ${ }^{24}$ Para petani sangat senang dengan wacana IG, karena mereka merasa mendapatkan pengakuan. Namun seiring waktu, wacana IG tidak dilanjutkan.

7. Mengajukan ke Direktorat Jenderal Perkebunan Kementrian Pertanian pada tahun 2015 dan mendapatkan anggaran pendampingan IG sebesar 600 juta pada tahun 2016, namun karena adanya kebijakan pemangkasan anggaran oleh pemerintah, maka anggaran pendampingan IG Kabupaten Malang menjadi dihapus. ${ }^{25}$

8. Dinas Tanaman Pangan, Hortikultura dan Perkebunan Kabupaten Malang untuk sementara hanya memfasilitasi pendaftaran varietas tanaman baru di Kementrian Pertanian yang dibuat oleh petani lokal, seperti varietas jeruk keprok, apel Batu55, durian kuning amat dan kelengkeng mutiara. ${ }^{26}$

Pernyataan yang sama juga disampaikan oleh bidang tanaman pangan, selama ini mereka hanya focus mendaftarkan varietas tanaman baru para petani lokal. Para pejabat pemerintah daerah banyak yang belum paham dengan indikasi geografis dan obyek yang bisa didaftarkan adalah bukan hanya sumber daya alam saja seperti hasil produksi pertanian, tapi juga barang kerajinan tangan, dan hasil industri.

Selain peran Dinas Tanaman Pangan, Hortikultura dan Perkebunan, juga terdapat lembaga lain yang berpeluang dapat ikut berperan dalam melakukan pembinaan IG, yaitu Dinas Perindustrian dan Perdagangan (Disperindag). Lembaga ini diberikan kewenangan untuk memberikan pembinaan terhadap industrilokal yaitu, mulai dari perijinan sampai pengurusan merek. Indikasi Geografis merupakan bagian dari obyek pembahasan di dalam UU No. 20 Tahun 2016 tentang Merek dan Indikasi Geografis, yang tentunya jika dilakukan sosialisasi adalah satu paket pembahasan yang sama. Namun di dalam prakteknya Disperindag belum memahami IG. ${ }^{27}$ Disperindag hanya memahami merek saja. Minimnya sosialisasi IG oleh Disperindag dan juga persoalan sering terjadinya penggantian staf dan pejabat di lingkungan Pemerintah Daerah Kabupaten Malang, menyebabkan IG belum tersosialisasikan secara optimal.

Ketiga, kultur hukum (legal culture). Menurut Friedman, kultur hukum adalah sikap manusia terhadap hukum dan sistem hukum, kepercayaan, nilai, pemikiran, serta harapannya. Budaya hukum erat kaitannya dengan kesadaran hukum masyarakat. Semakin tinggi kesadaran hukum masyarakat maka akan tercipta budaya hukum yang baik dan dapat merubah pola pikir masyarakat mengenai hukum. Masyarakat petani di Kabupaten Malang yang pernah diberikan pembinaan oleh Dinas Tanaman Pangan, Hortikultura dan Perkebunan adalah hanya di Kecamatan Dampit saja yaitu pada tahun 2015. Berdasarkan hasil wawancara dengan petani menjelaskan bahwa petani sangat senang dengan keberadaan IG, namun tetap harus ada support proaktif dari pemerintah daerah. Peran gapoktan untuk proaktif dalam membentuk kepemilikan IG dalam komunitas juga sangat diperlukan.

\footnotetext{
${ }^{24}$ Kholida, Kasi Produksi Perkebunan Dinas Tanaman Pangan, Hortikultura dan Perkebunan. (Senin, 8 Juli 2019). Hasil Wawancara.

${ }^{25}$ Widodo, Budi. Kasi Produksi Pembenihan dan Perlindungan Hortikultura. (Sabtu, 29 September 2019). Hasil Wawancara.

26 Suntoro, Heri. Kabid Hortikultura, Dinas Pertanian Tanaman Pangan, Hortikultura dan Perkebunan. (Jumat, 30 Agustus 2019). Hasil Wawancara.

${ }^{27}$ Supraptiwi. Kasi Industri Hasil Pertanian dan Kehutanan, Disperindag. (23 Agustus 2019). Hasil Wawancara.
} 


\subsection{Upaya Perlindungan IG Oleh Pemerintah Daerah Kabupaten Malang dalam Perspektif Keadilan}

Perlindungan hukum bagi produk masyarakat lokal melalui IG merupakan bagian dari keadilan yang diberikan terhadap masyarakat lokal. Sebagaimana halnya dengan Merek, IG merupakan salah satu bentuk kekayaan intelektual yang wajib diupayakan perlindungannya bagi negara-negara anggota World Trade Organization. Ketentuan mengenai hal tersebut tertuang dalam Trade Related Intellectual Property Rights (TRIPs) khususnya Article 22 sampai dengan Article 24. Untuk melaksanakan kewajiban tersebut, Indonesia telah mengatur IG melalui pasal 53 Undang-Undang Nomor 20 Tahun 2016 tentang Merek dan Indikasi Geografis.

John Locke mengajarkan konsep kepemilikan dengan hak asasi manusia dengan pernyataannya life, liberty, and property. Manusia memiliki hak alami yang diberikan oleh Tuhan untuk kehidupan, kebebasan dan mendapatkan harta kekayaan. ${ }^{28}$ Locke menjelaskan bahwa manusia adalah sederajat dalam status naturalis, kewajiban orang satu sama lainnya adalah sama sebagaimana haknya. Semua orang memiliki kewajiban untuk tidak merugikan orang lain, kecuali dalam kasus tertentu ${ }^{29}$ :

a. All persons have a liberty right to dispose of their efforts as they see fit.

b. All persons have a liberty right to use the common "the earth and all its fruit which God give to humankind."

Penggunaan hak tidak boleh merugikan masyarakat, sebagaimana Locke menyatakan: ${ }^{30}$

a. Our claim right to be free from harm

$b$. Our claim right to have a share of others plenty in times of our great need

c. Our liberty right to use the common

Hasil produksi masyarakat lokal adalah dimiliki masyarakat sendiri, tidak boleh ada individu yang melakukan pengakuan. Indikasi geografis merupakan hak milik komunal, menurut hukum alam, secara alami hak tersebut tidak boleh ada seorangpun yang mengklaim atas kepemilikan komunal. Kepemilikan individu tidak boleh merugikan masyarakat.

Friedrick Hegel melengkapi konsep John Locke mengembangkan konsep right, ethic, and state. Pengakuan hak seseorang harus disertai dengan etika dalam penggunaanya. ${ }^{31}$ Peran negara penting dalam menjaga hak seseorang dan etika penggunaan hak. Perlindungan hukum bagi masyarakat yang memiliki hasil produksi lokal yang mempunyai karakteristik tertentu karena factor alam dan manusia tentunya menjadi tanggung jawab negara untuk memberikan perlindungan hukum, jika ada seseorang yang melakukan klaim atas identitas masyarakat tersebut. Secara etika seseorang juga tidak boleh melakukan pengakuan atas kepemilikan masyarakat tertentu. Peran negara bukan hanya mengatur dalam norma saja, namun juga implementasinya untuk mewujudkan keadilan.

${ }^{28}$ Harris, J. W. (2001). Property and Justice. London: Oxfords University Press, p. 188-201.

29 Nasution, R.J.P. (2013). Interface Hukum Kekayaan Intelektual dan Hukum Persaingan. Jakarta: Rajawali Pers, p. 24-25.

30Porter, R.B., Pierre Sauve at.all. (2001). Efficiency, Equity and Legitimacy: Multilateral Trading System at The Millenium. Washington D.C: Brooking Institute Press, p. 34-39.

${ }^{31}{ }^{\prime}$ 'Amato, A.A.\& Long, D.E. (1996). International Intellectual Property Anthology.

Anderson Publishing(1996). International Intellectual Property Anthology. Anderson Publishing, p. 29-36 
Pembahasan mengenai keadilan dapat dilihat dua pemahaman yang berbeda. Pertama adalah aliran filsafat konseptual yang berasal dari Eropa Kontinental yang menjelaskan bahwa keadilan hanya secara filsafat saja dan tidak sampai pada penerapannya. Menurut aliran ini, "hukum yang benar adalah hukum yang bernuansa keadilan", yaitu hukum memberikan kepada orang apa yang menjadi haknya (ius suum cuique tribuere), sehingga kemudian muncul konsep Aristotle dan Thomas Aquinas, yakni: 32

1. Persamaan proporsional (justicia distributiva)

2. Keseimbangan prestasi (justicia commutativa)

Pengaturan IG di Indonesia melalui UU No. 20 tahun 2016 telah memberikan keadilan bagi masyarakat lokal yang ingin memiliki identitas atas hasil produksi lokal yang menjadi ciri khas karena adanya faktor sumber daya alam ataupun peran manusia yang ada di daerah tertentu. Keadilan proporsional yang diberikan kepada masyarakat lokal di Indonesia untuk mendapatkan pengakuan identitas di wilayah hukum di Indonesia, dan tidak boleh digunakan oleh perorangan ataupun badan usaha, karena IG adalah milik komunal dan hanya boleh dimiliki oleh mayarakat itu sendiri atau lembaga yang diberikan kewenangan seperti pemerintah daerah. Sebagaimana diatur melalui Pasal 68 (1) UU No. 20 Tahun 2016 menyatakan bahwa:

“(1) Dalam hal sebelum atau pada saat dimohonkan pendaftaran sebagai Indikasi Geografis, suatu tanda dipakai dengan iktikad baik oleh pihak lain yang tidak berhak mendaftar menurut ketentuan sebagaimana dimaksud dalam Pasal 53 ayat (3), pihak yang beriktikad baik tersebut tetap dapat menggunakan tanda tersebut untuk jangka waktu 2 (dua) tahun terhitung sejak tanda tersebut terdaftar sebagai Indikasi Geografis.

(2) Dalam hal tanda sebagaimana dimaksud pada ayat (1) telah terdaftar sebagai Merek, Menteri membatalkan dan mencoret pendaftaran Merek tersebut untuk seluruh atau sebagian jenis barang yang sama setelah jangka waktu 2 (dua) tahun terhitung sejak tanda tersebut terdaftar sebagai Indikasi Geografis."

Ketentuan tersebut telah memberikan keadilan bagi masyarakat lokal, mereka diberikan prioritas kepemilikan identitas dalam bentuk IG daripada kepemilikan identitas dalam bentuk merek oleh pribadi atau perusahaan. Merek dagang akan dihapus setelah digunakan selama 2 tahun terhitung terdaftarnya IG. Prioritas ini tentunya memberikan keadilan bagi identitas traditional knowledge mayarakat lokal melalui perlindungan IG. Keadilan melalui keseimbangan kepemilikan pribadi dan komunal menjadi penting dilakukan untuk melindungi traditional knowledge masyarakat lokal.

Kedua adalah keadilan dalam perspektif aliran filsafat analitis yang berasal dari Anglo Amerika yang dipelopori oleh John Rawl yang berpikir bahwa keadilan adalah dilihat sampai pada implementasinya. Titik tolak aliran ini adalah keadilan sebagai kejujuran (justice as fairness). Berkaitan dengan pandangan ini terdapat dua prinsip keadilan (the principle of justice), yaitu:

32Nasution, R.J.P., (2013). Interface Hukum Kekayaan Intelektual dan Hukum Persaingan. Jakarta: Rajawali Pers, p. $45-46$. 
a. Keadilan yang berkaitan dengan kebebasan (liberty). Keadilan menuntut setiap orang mempunyai hak yang sama terhadap kebebasan. Perlindungan hak kekayaan intelektual diberikan bukan hanya untuk melindungi hak individu saja, tapi juga melindungi hak masyarakat/komunal. Kepemilikan merek dan IG adalah salah satu bentuk keadilan yang proporsional. Kebebasan atas hak kepemilikan individu mempunyai batasan bahwa kepemilikannya tidak boleh mengambil hak kepemilikan sosial.

b. Ketidaksamaan dalam sosial ekonomi (sosial economi inequality) harus ditata untuk mewujudkan keadilan tersebut. Upaya yang bisa dilakukan untuk mewujudkan keadilan adalah penataan diarahkan pada kemanfaatan terbesar bagi kelompok yang tidak diberikan banyak keuntungan. Penataan keadilan dalam sosial ekonomi tentunya perlu ada peran pemerintah. Hasil kreatifitas dan produksi lokal masyarakat tentunya membutuhkan peran pemerintah daerah untuk memberikan perlindungan hukum bagi masyarakat lokal. Peran aktif pemerintah daerah sangat penting sekali dalam memberikan kebijakannya untuk meningkatkan sosdial ekonomi masyarakat daerah.

Pemerintah telah mengatur perlindungan masyarakat melalui IG, namun keadilan yang terdapat di dalam norma dalam hal ini UU Merek dan IG tidak dapat tercapai jika keadilan tidak diwujudkan dalam implementasinya. Perumusan norma hukum IG dalam UU Merek dan IG merupakan bentuk perlindungan hukum bagi rakyat yang merupakan prinsip pengakuan dan perlindungan terhadap harkat dan martabat manusia, dalam hal ini adalah masyarakat lokal. Pemahaman atas prinsip perlindungan hukum bagi rakyat dapat ditentukan melalui sarana perlindungan hukum yang tepat. Perlindungan hukum preventif bagi masyarakat lokal tidak bisa hanya diatur melalui peraturan perundang-undangan, namun juga harus perlu peran aktif pemerintah dalam implementasinya, karena bagian dari perlindungan terhadap kekayaan budaya bangsa.

Jeremy Bentham sebagai pelopor paham utilitarian memaknai sisi akibat dari suatu tindakan bahwa perbuatan itu harus sebanyak mungkin memberikan kebahagiaan kepada sebagian besar orang (the greatest happiness for the greatest number), termasuk campur tangan negara harus memberikan akibat yang terbaik bagi masyarakat. Bentham memperlakukan kekayaan (property) dalam terminologi pengharapan (expectation) dan kemanfaatan (utility), dengan pernyataannya:" property is nothing but a basis of expectation, the expectation deriving certain advantages from a thing which we are said to process in consequence of the relation in which we stand towards it". ${ }^{33}$

Bagi masyarakat lokal yang memiliki ciri-ciri karakteristik indikasi geografis, tentunya peran negara melalui pemerintah daerah sangat penting. Tidak semua petani mengetahui IG. Selain pengaturan yang memberikan perlindungan terhadap kekayaan masyarakat tradisional melalui IG, namun pemerintah daerah juga harus mampu mewujudkan kebahagiaan dan kemanfaatan bagi harta kekayaan milik masyarakat lokal ketika masayarakat membutuhkannya. Sebagaimana yang terdapat di dalam

${ }^{33}$ Munzer, S R. (2002). A Theory of Property. Cambridge: Cambridge University Press, p. 156-158. 
pasal 70 (2) UU Merek dan Indikasi Geografis, pemerintah mempunyai peran dalam memberikan perlindungan identitas traditional knowledge masyarakat lokal:

Pembinaan IG yang dilakukan oleh pemda ataupun pemerintah pusat meliputi:
a. persiapan untuk pemenuhan persyaratan Permohonan IG;
b. permohonan pendaftaran IG;
c. pemanfaatan dan komersialisasi IG;
d. sosialisasi dan pemahaman atas pelindungan IG;
e. pemetaan dan inventarisasi potensi produk IG;
f. pelatihan dan pendampingan;
g. pemantauan, evaluasi, dan pembinaan;
h. pelindungan hukum; dan
i. fasilitasi pengembangan, pengolahan, dan pemasaran barang dan/atau produk IG.

Istilah manfaat (utility) dengan kesejahteraaan (welfare), menjelaskan bahwa prinsip manfaat, memerintahkan pemuasan tertinggi dari keistimewaan yang dari semua orang. Peran pemerintah daerah dalam pemetaan dan inventarisasi potensi produk IG merupakan bagian upaya memberikan pemuasan masayarakat lokal untuk mendapatkan haknya, memberikan kemanfaatan nilai ekonomi bagi produk lokal sehingga kesejahteraan masyarakat lokal meningkat. Hal ini seiring dengan upaya pemerintah melalui Undang-Undang Merek dan Indikasi Geografis yang sekarang telah memberikan kemudahan kepada masyarakat lokal dalam mengembangkan ekonomi lokal. ${ }^{34}$ Perekonomian daerahakan semakin meningkatdengan adanya pengaturan IG terbaru. ${ }^{35}$

Konsep keadilan yang dikonsepsikanoleh Muhammad Hatta dan diamanatkan konstitusi menjadi landasan bagi pemerintah untuk selalu memberikan keadilan sosial bagi masyarakatnya. Upaya pemerintah pusat dan daerah harus senantiasa bekerjasama untuk ikut membantu menciptakan keadilan sosial. Kabupaten Malang sebagai daerah yang mempunyai banyak pengetahuan, tradisi, dan budaya, serta iklim tropis yang menghasilkan berbagai macam barang yang memiliki potensi ekonomi yang besar, guna mewujudkan keadilan sosial, sudah seharusnya Kabupaten Malang memiliki sistem perlindungan IG. Melalui perlindungan IG yang optimal, maka kelestarian lingkungan Kabupaten Malang diharapkan dapat terjaga, pemberdayaan sumber daya alam dan manusia di daerah diharapkan dapat lebih dioptimalkan. Di samping itu, dengan tercipta/terbukanya peluang dan lapangan kerja untuk menghasilkan barang tertentu yang dilindungi IG dapat meningkatkan perekonomian daerah dan diharapkan dapat memiliki nilai ekonomi yang besar di suatu daerah.

\section{Kesimpulan}

\footnotetext{
34Sudjana. (2018). Implikasi Perlindungan Indikasi Geografis Berdasarkan Undang-Undang Nomor 20 Tahun 2016 Terhadap Pengembangan Ekonomi Lokal, Veritas Et Justitia, 4 (1), p.53. doi: 10.25123 /vej. 2915

${ }^{35}$ Apriansyah, N. (2018). Perlindungan Indikasi Geografis Dalam Rangka Mendorong Perekonomian Daerah. Jurnal Penelitian Hukum De Jure, 18 (4), 525-542. doi.org/10.30641/dejure.2018.v18.525-542.
} 
Upaya yang sudah dilakukan oleh pemerintah daerah Kabupaten Malang dalam memberikan perlindungan hukum bagi masyarakat petani lokal dalam menghadapi pasar bebas AEC adalah mengajukan permohonan pendaftaran indikasi geografis (IG) Kopi lereng semeru kepada Propinsi Jawa Timur pada tahun 2015, mengajukan kepada Bupati, dan belum mendapatkan persetujuan DPRD Kabupaten Malang untuk dapat menganggarkan pendaftaran IG pada tahun 2015. Kepemilikan merek dan IG adalah salah satu bentuk keadilan yang proporsional. Kebebasan atas hak kepemilikan individu mempunyai batasan bahwa kepemilikannya tidak boleh mengambil hak kepemilikan sosial.Upaya yang bisa dilakukan untuk mewujudkan keadilan adalah penataan diarahkan pada kemanfaatan terbesar bagi kelompok yang tidak diberikan banyak keuntungan. Penataan keadilan dalam sosial ekonomi tentunya perlu ada peran pemerintah. Hasil kreatifitas dan produksi lokal masyarakat tentunya membutuhkan peran pemerintah daerah untuk memberikan perlindungan hukum bagi masyarakat lokal. Peran aktif pemerintah daerah sangat penting sekali dalam memberikan kebijakannya untuk meningkatkan sosial ekonomi masyarakat daerah.Bagi masyarakat lokal yang memiliki ciri-ciri karakteristik IG, tentunya peran negara melalui pemerintah daerah sangat penting. Selain membuat pengaturan yang memberikan perlindungan terhadap kekayaan masyarakat tradisional melalui IG, pemerintah daerah juga harus mampu mewujudkan kebahagiaan dan kemanfaatan bagi harta kekayaan milik masyarakat lokal ketika masyarakat membutuhkannya. Pendaftaran IG kopi lereng semeru oleh pemerintah daerah akan memberikan manfaat dan keadilan bagi mayarakat petani tersebut.

\section{Daftar Pustaka}

\section{Buku}

D'Amato, A.A \& Long, D.E. (1996). International Intellectual Property Anthology. Anderson Publishing

Friedman, L, M. (2001). American Law: An Introduction, Second Edition. Jakarta: Tatanusa.

Friedman, L, M. (2013). Sistem Hukum Perspektif Ilmu Sosial, The Legal System: A Sosial S cience Perspective. Bandung: Nusamedia.

Harris, J. W. (2001). Property and Justice. London: OxfordUniversity Press,

Mahkamah Agung RI. (1998). GATT, TRIPS dan Kekayaan Intelektual.

Munzer, S. R. (2002). A Theory of Property. Cambridge: Cambridge University Press.

Nasution, R.J.P. (2013). Interface Hukum Kekayaan Intelektual dan Hukum Persaingan.

Jakarta: Rajawali Pers.

Porter, R. B., Pierre Sauve at.all. (2001). Efficiency, Equity and Legitimacy: Multilateral Trading System at The Millenium. Washington D.C: Brooking Institute Press.

Septiono, S. (2009). Perlindungan Indikasi Geografisdan Potensi Indikasi Geografis

Indonesia. Dirjen Kekayaan Intelektual,.

\section{Jurnal}


Ardana, K. (2017). Kinerja Kelembagaan Perlindungan Indikasi Geografis Kopi Kintamani,Agricore, Jurnal Agribisnis dan Sosial Ekonomi Pertanian, 2 (1), 205-290.

Apriansyah, N. (2018). Perlindungan Indikasi Geografis Dalam Rangka Mendorong Perekonomian Daerah. Jurnal Penelitian Hukum De Jure, 18 (4), 525542.doi.org/10.30641/dejure.2018.v18.525-542.

Aridhayandi, M. R. (2017). Focus Group Discussion Mengenai Pemahaman Perubahan Aturan Hukum Indikasi Geografis Bagi Masyarakat Pelestari Padi Pandanwangi Cianjur (Mp3c) Sebagai Pemegang Hak Indikasi Geografis Terdaftar. Journal Of Empowerment UniversitasSuryakancana, 1 (2), 87-102. doi.org/10.35194/je.v1i2.200

Indikasi Geografis Kabupaten Kudus. Law Reform, 12 (2), p. 288-304. doi.org/10.14710/ lr.v12i2.15881.

Lukito, I. (2018). Peran Pemerintah Daerah Dalam Mendorong Potensi Indikasi Geografis (Studi Pada Provinsi Kepulauan Riau). Jurnal Ilmiah Kebijakan Hukum, 12 (3), 313-330. doi.org/10.30641/ kebijakan.2018.v12.313-330.

Pratama, T.G.W dan Roisah, K. (2017). Potensi Pendaftaran Kretek SebagaiIndikasi Geografis Kabupaten Kudus. Law Reform, 12 (2), p. 288-304. doi.org/10.14710/ lr.v12i2.15881.

Rifai, T.P. (2017). Kesiapan Undang-Undang Nomor 20 Tahun 2016 Tentang Merek Dan Indikasi Geografis Dalam Menghadapi Masyarakat Ekonomi Asean. Fiat Justisia, 10 (4), 733-776. doi.org/10.25041/ fiatjustisia.v10no4.809.

Sudjana. (2018). Implikasi Perlindungan Indikasi Geografis Berdasarkan Undang-Undang Nomor 20 Tahun 2016 Terhadap Pengembangan Ekonomi Lokal, Veritas Et Justitia, 4 (1), p.53. doi: 10.25123/vej.2915.

\section{Internet}

Http://www.wipo.int/geo_indications/en/about.html.

Http:// www. Malangkab.go.id. Kopi Asal Kabupaten Malang Jadi Idola Dunia Http:// www. dgip.go.id. Indikasi Geografis Terdaftar Januari Tahun 2015

\section{Peraturan Perundang-Undangan}

Undang-Undang Nomor. 20 tahun 2016 tentang Merek dan Indikasi Geografis

Peraturan Pemerintah No. 51 Tahun 2007 tentang Indikasi Geografis 